\title{
Hexabothriid monogeneans from the gills of deep-sea sharks off Algeria, with the description of Squalonchocotyle euzeti n. sp. (Hexabothriidae) from the kitefin shark Dalatias licha (Euselachii, Dalatiidae)
}

\author{
H. KHEDDAM ${ }^{1}$, J.-L. JUSTINE² , F. TAZEROUTI*
}

'Laboratoire de Parasitologie, Faculté des Sciences Biologiques; Université des Sciences et de la Technologie Houari Boumediene (USTHB) BP. 32, El Alia Bab Ezzouar, 16111 Alger, Algeria, E-mail: houda.khedam@yahoo.fr, ${ }^{*}$ tazerouti_fd@yahoo.fr, ${ }^{2}$ ISYEB, Institut de Systématique, Évolution, Biodiversité (UMR7205 CNRS, EPHE, MNHN, UPMC), Muséum National d'Histoire Naturelle, Sorbonne Universités, CP 51, 55 rue Buffon, 75231 Paris cedex 05, France, E-mail: justine@mnhn.fr

Article info

Received June 13, 2016 Accepted September 20, 2016

\section{Summary}

Sharks (765 specimens from ten species) from the Mediterranean Sea off Algiers, Algeria, were examined for the presence of gill monogeneans. The following deep-sea sharks were investigated from 2009 to 2015: Centrophorus granulosus (27 specimens); Centrophorus uyato (39); Etmopterus spinax (67); Somniosus rostratus (19); Galeus melanostomus (189); Scyliorhinus canicula (261), Hexanchus griseus 3), and Dalatias licha (100). In addition, two pelagic shark species were examined: Alopias vulpinus (7), and Prionace glauca (53). Only two species of gill monogeneans were found. Protocotyle grisea (Cerfontaine, 1899) Euzet et Maillard, 1974 was found on its type-host Hexanchus griseus; comparative measurements are provided, and Algeria is a new geographic record. Squalonchocotyle euzeti n. sp. from Dalatias licha is described here. We found that the species of Squalonchocotyle Cerfontaine, 1899 can be separated into two groups, according to body size. Small-bodied species include 7 species. Large-bodied species (body $>20 \mathrm{~mm}$ ) include $S$. borealis (Van Beneden, 1853), S. laymani Yamaguti, 1958 and S. euzeti $\mathrm{n}$. sp; the latter is distinguished from the two other species by a characteristically slender body. A sequence of Cytochrome Oxidase Type I (COI) gene, potentially useful for barcoding, was obtained for $S$. euzeti n. sp. and is the first for the family Hexabothriidae.

Keywords: Monogenea; Protocotyle grisea; parasitological survey; barcoding

\section{Introduction}

From 2009 to 2015, we examined sharks from off Algeria, mainly deep-sea species, for gill monogeneans. Only two species of gill monogeneans were collected, although ten species of sharks and 765 shark specimens were investigated. One was Protocotyle grisea (Cerfontaine, 1899) Euzet et Maillard, 1974 from Hexanchus griseus, for which we provide measurements; the other is a species of Squalonchocotyle Cerfontaine, 1899 which we describe herein as a new species.

\section{Material and Methods}

\section{Sharks}

Sharks were obtained from fishermen in Dellys $\left(36^{\circ} 55^{\prime} \mathrm{N} ; 3^{\circ} 53^{\prime} \mathrm{E}\right)$, Cap Djenet ( $\left.36^{\circ} 43^{\prime} \mathrm{N} ; 3^{\circ} 36^{\prime} \mathrm{E}\right)$, Bou Haroun ( $\left.36^{\circ} 40^{\prime} \mathrm{N} ; 4^{\circ} 40^{\prime} \mathrm{E}\right)$, and Cherchell $\left(36^{\circ} 37^{\prime} \mathrm{N} ; 2^{\circ} 11^{\prime} \mathrm{E}\right)$. All four localities are on the Mediterranean coast within $100 \mathrm{~km}$ near Algiers, Algeria and thus results are not detailed according to the localities. The following deep-sea shark species were examined for gill monogeneans from 2009 to 2015: gulper shark, Centrophorus granulosus (Bloch et 


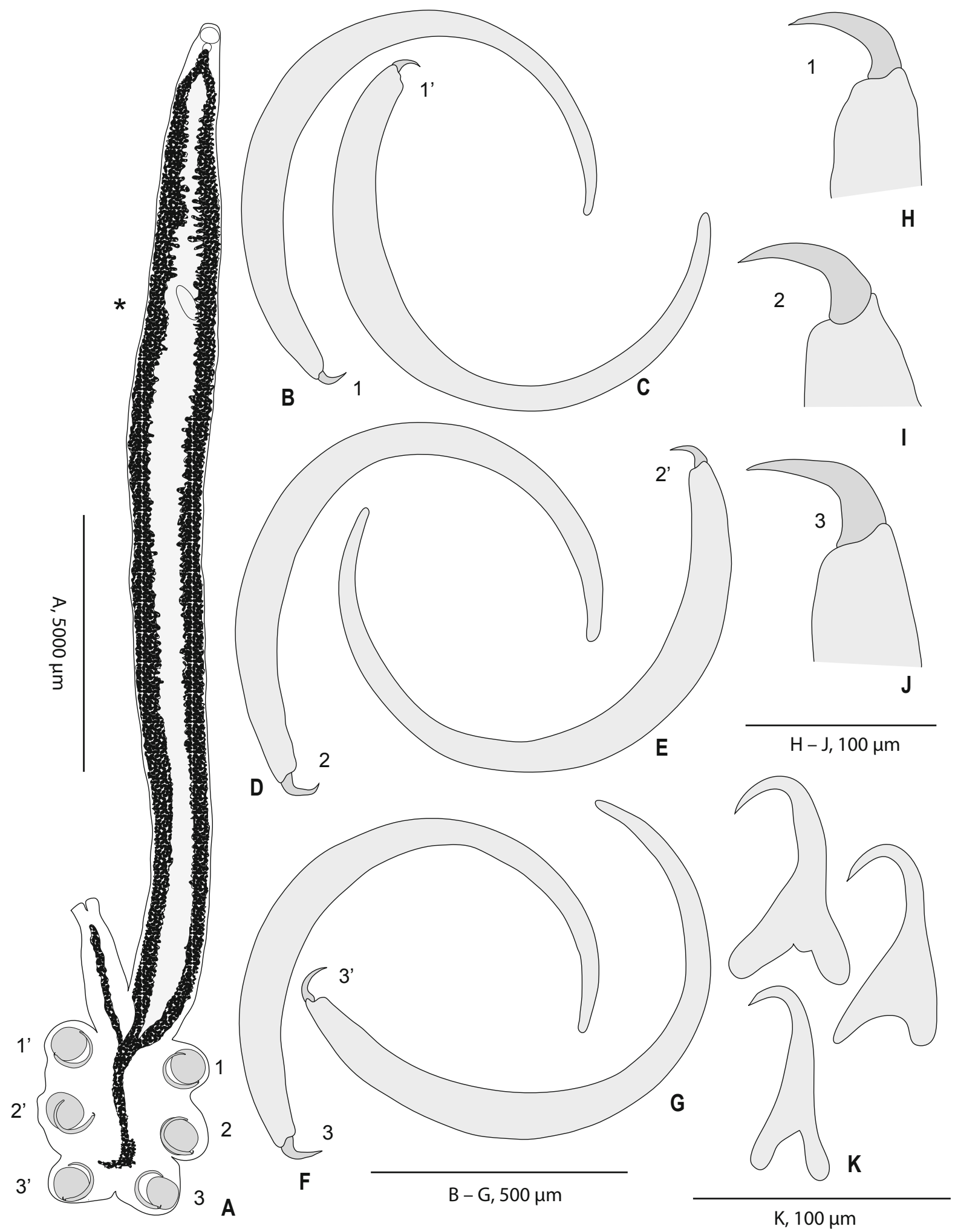

Fig. 1. Squalonchocotyle euzeti n. sp. from Dalatias licha off Algeria. A, holotype, whole body. Due to the slender body, only limited anatomy is represented. Asterisk, level of seminal receptacle (outline of seminal receptacle drawn) and ovary. B - G, sclerites. $\mathrm{H}-\mathrm{J}$, extremities of sclerites. For $A-J$, numbers of sclerites are indicated. $K$, hamuli of various specimens. A-J, holotype; $K$, paratypes. 


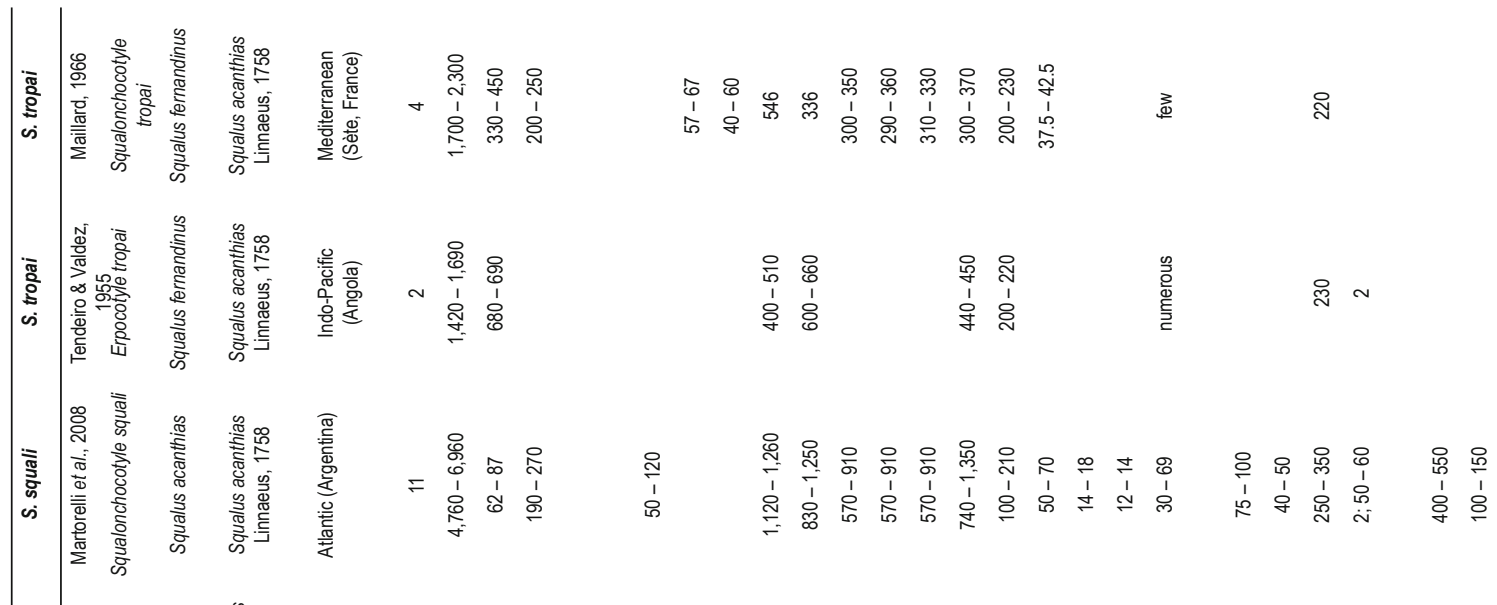

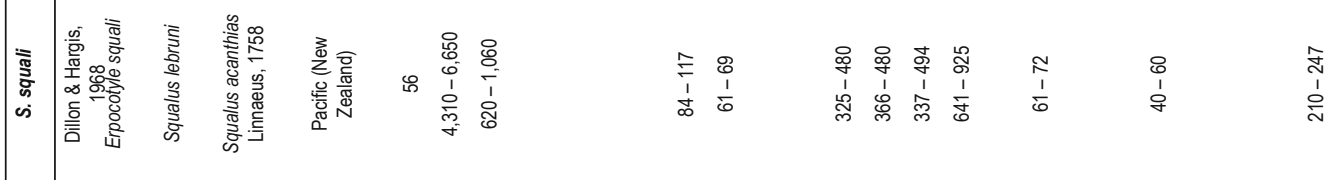

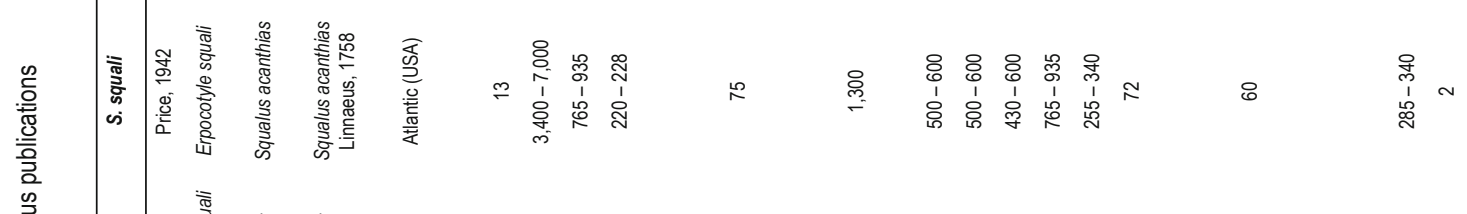

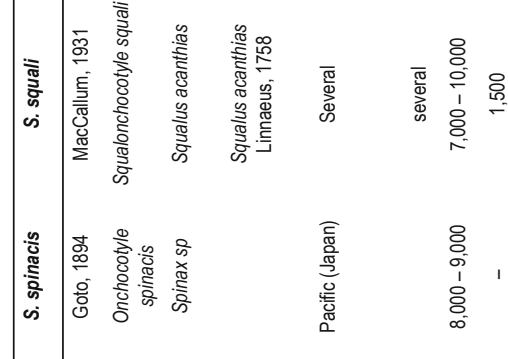

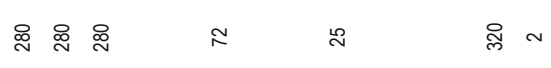

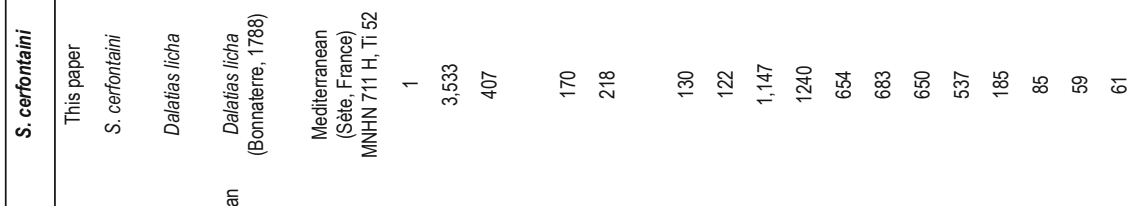

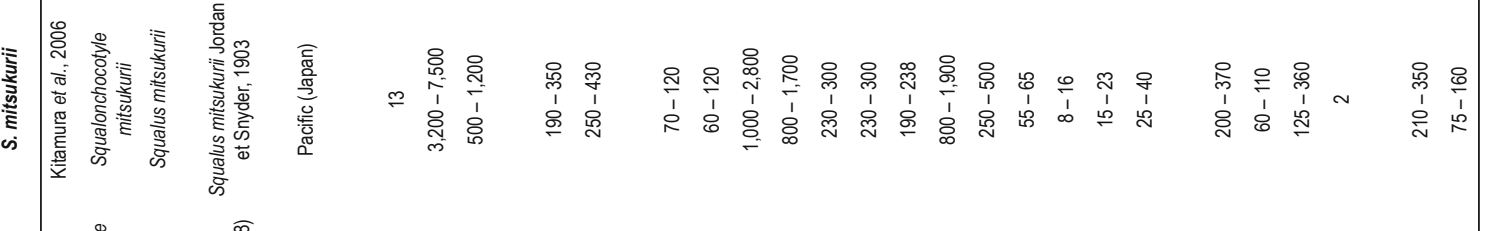

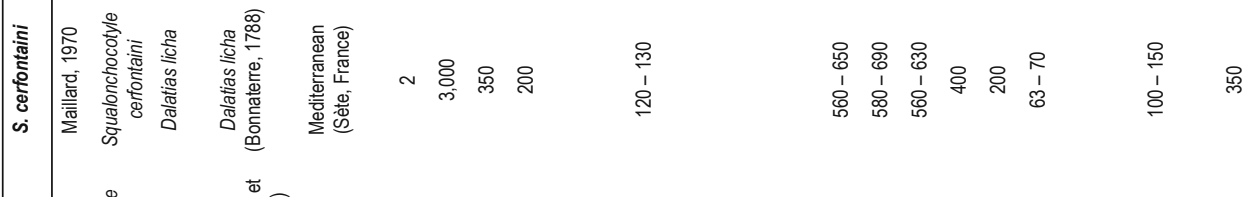

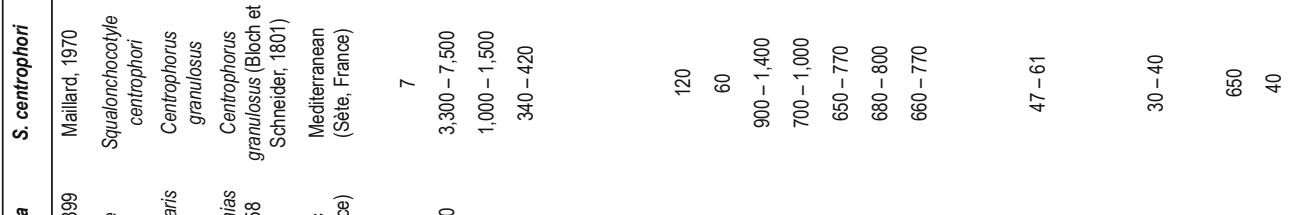

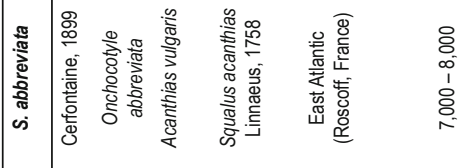

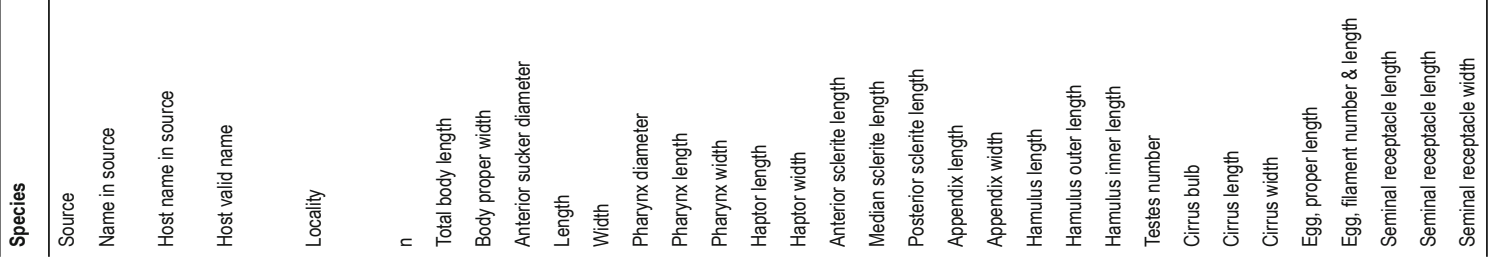


Schneider, 1801): 27 specimens; little gulper shark, Centrophorus uyato (Rafinesque, 1810): 39; velvet belly, Etmopterus spinax (Linnaeus, 1758): 67; little sleeper shark, Somniosus rostratus (Risso, 1827): 19; blackmouth catshark, Galeus melanostomus Rafinesque, 1810: 189; lesser spotted dogfish, Scyliorhinus canicula (Linnaeus, 1758): 261; bluntnose sixgill shark, Hexanchus griseus (Bonnaterre, 1788): 3; and kitefin shark, Dalatias licha (Bonnaterre, 1788): 100. In addition, two pelagic shark species were examined: thresher, Alopias vulpinus (Bonnaterre, 1788), 7 specimens, and blue shark, Prionace glauca (Linnaeus, 1758), 53. Sharks were collected as fresh as possible, photographed and immediately brought back to the laboratory for examination. Identification was done according to usual keys (Fischer et al., 1987). The parasitological survey and fish identifications were done by HK.

\section{Monogeneans}

The gills were removed and observed in filtered seawater for monogeneans. Monogeneans, located using a stereo-microscope were removed alive (dead for the few specimens from $H$. griseus) from between the gill lamellae and were studied either directly or fixed, slightly flattened, between a slide and cover slip. Monogeneans were fixed either with ethanol or Bouin's fixative. Specimens were stained with carmine, cleared in clove oil and mounted in Canada balsam. Specimens for molecular analysis were collected in $95 \%$ ethanol. All drawings were made with the help of an Olympus $\mathrm{BH}-2$ microscope drawing tube. Drawings were scanned and redrawn on a computer with Adobe Illustrator. Measurements are in micrometres.

\section{Molecular sequences}

We used a QIAmp DNA Micro Kit (Qiagen) to extract DNA. Elution was performed in $60 \mu \mathrm{L}$. The specific primers JB3 (=COI-ASmit1) (forward 5'-TTTTTTGGGCATCCTGAGGTTTAT-3') and JB4.5 (=COI-ASmit2) (reverse 5'-TAAAGAAAGAACATAATGAAAATG-3') were used to amplify a fragment of the COI gene (Bowles et al., 1995; Littlewood et al., 1997). The PCR reaction was performed in $20 \mu \mathrm{l}$, containing $1 \mathrm{ng}$ of DNA, $1 \times$ CoralLoad PCR buffer, $3 \mathrm{mM}$ $\mathrm{MgCl} 2,66 \mu \mathrm{M}$ of each dNTP, $0.15 \mu \mathrm{M}$ of each primer, and 0.5 units of Taq DNA polymerase (Qiagen). The amplification protocol was: 4' at $94^{\circ} \mathrm{C}$, followed by 40 cycles of $94^{\circ} \mathrm{C}$ for $30^{\prime \prime}, 48^{\circ} \mathrm{C}$ for $40^{\prime \prime}, 72^{\circ} \mathrm{C}$ for $50^{\prime \prime}$, with a final extension at $72^{\circ} \mathrm{C}$ for 7 '. Sequences were edited with CodonCode Aligner software version 3.7.1 (CodonCode Corporation, Dedham, MA, USA), compared to the GenBank database content with BLAST, and deposited in GenBank under accession numbers KX389260 - KX389262. Trials to obtain 28S partial sequences with the routine method previously used for other polyopisthocotylean monogeneans (Justine et al., 2013) were unsuccessful.

\section{Results}

Parasitological survey

Among the 765 sharks examined over six years, belonging to ten species, only two species had monogeneans on their gills. Hexan- chus griseus had Protocotyle grisea, and Dalatias licha had a new species of Squalonchocotyle.

\section{Protocotyle grisea (Cerfontaine, 1899) Euzet et Maillard, 1974}

\section{Brief description of the material from Algeria}

Our specimens were not in optimal state of conservation because these sharks were not fresh; however, the sclerotised parts could be observed and measured. Measurements (in parenthesis, measurements in Justine, 2011 for comparison): anterior sclerites

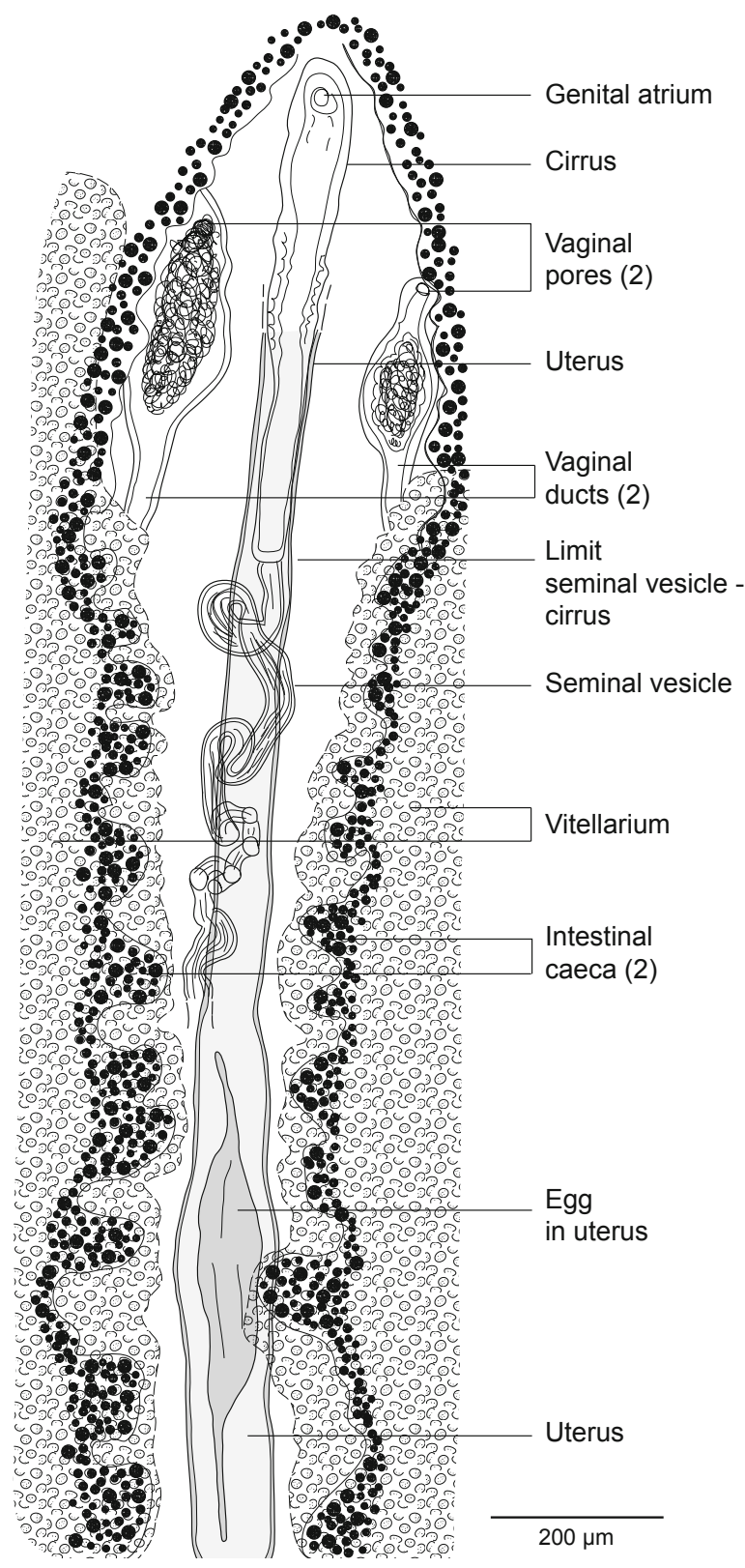

Fig. 2. Squalonchocotyle euzeti $\mathrm{n}$. $\mathrm{sp}$ Anatomy of anterior part of reproductive system 
$1,480-2,054(1,680-1,720) ;$ median sclerites $1,850-2,498$ (1,950 - 2,550); posterior sclerites 1,795 - 2,331 (1,820 - 2,330); hamulus outer length $89-96(66-88)$; hamulus inner length 74 $-85(70-85)$.

\section{Taxonomic summary}

Type host: Hexanchus griseus Bonnaterre, 1788

Type locality: Naples, Italy (Cerfontaine, 1899)

Additional localities: Trieste (Italy) (Cerfontaine, 1899); Sète (France) (Maillard \& Oliver, 1966; Euzet \& Maillard, 1974); near Algiers (Algeria) (this paper).

Specimens examined: 7 specimens from 3 host fish.

Prevalence in Algeria: 100 \% (3/3).

Material deposited: MNHN, slides HEL558.

\section{Remarks}

Measurements of our specimens from Algeria are consistent with an identification with $P$. grisea and allow to differentiate the specimens from the two only other species in the genus, namely Protocotyle taschenbergi (Maillard et Oliver,1966) Euzet et Maillard, 1974 and Protocotyle euzetmaillardi Justine, 2011 (Maillard \& Oliver, 1966; Euzet \& Maillard, 1974; Justine, 2011). Algeria is a new geographical record for the species.

\section{Squalonchocotyle euzeti n. sp.}

\section{Description}

Based on 32 specimens; measurements in Table 2, including separate measurements for holotype and means for all specimens.

Body elongate, slender, haptor wider than body. Haptor symmetrical, armed with six suckers, each provided with hook-shaped sclerite, and appendix bearing single pair of terminal suckers and single pair of hamuli, each with one sclerite. Haptoral sclerites in 3 pairs arranged symmetrically, each with same shape and with point at right-angles to distal end of sclerite shaft; median sclerites slightly longer than those of anterior and posterior pairs. Appendix elongate, directed anteriorly in flattened specimens. Pair of hamuli with V-shaped root situated near distal end of appendix. Pair of terminal suckers oblong.

Anterior sucker terminal. Pharynx subspherical. Oesophagus short. Caeca internally moderately diverticulate, confluent in posterior part of body, end as two short caeca, one which extends into haptor and one into appendix.

Testes numerous, occupy intercaecal area of posterior part of body, end posteriorly before confluence of caeca. Single sperm duct (vasa efferentia) well visible from testes to seminal vesicle. Seminal vesicle, begins just anterior to oötype, convoluted, thinwalled, contains spermatozoa, continues anteriorly and connects with cirrus; no posterior lobe. Cirrus elongate, unarmed, connects with genital atrium. Prostatic glands not seen. Genital atrium ventral, median, just posterior to bifurcation of caeca.
Ovary located at mid-length of body proper; proximal part of ovary slightly branched; descending and ascending ovarian parts straight; ovary terminates as slender canal superposed to seminal receptacle. Connections of terminal ovary, anterior part of seminal receptacle, posterior part of ovovitelloduct, posterior part of median vitelloduct and genitointestinal canal apparently all located just anteriorly to seminal vesicle. Ovovitelloduct convoluted, without diverticulum, connects anteriorly with oötype. Seminal receptacle cylindrical, oblique with anterior connection. Two lateral vitelloducts unite to form posteriorly directed median vitelloduct, with coil. Oötype wall with longitudinal rows of large cells ('oötype côtelé' of Euzet and Maillard 1974). Mehlis' glands surround oötype. Oötype anteriorly joins uterus. Uterus straight, contains few eggs, ends anteriorly in genital atrium. Two vaginal openings, located just posteriorly to genital atrium or at the same level; anterior portion of vaginae often widened, filled with spermatozoa; posterior portion not well visible.

Eggs fusiform, elongate, operculum not seen, with two polar filaments.

Molecular information

We obtained COI sequences, $396 \mathrm{bp}$ in length, for three specimens; the sequences differed between them by 4 and 6 nucleotide $(1-1.5 \%)$. A GenBank BLAST of the sequences showed that the closest species were polystomatid polyopisthocotylean monogeneans. These sequences were widely different $(20-30 \%)$ as polystomatids and hexabothriids are not closely related family. COI sequences are generally appropriate for distinguishing species; in the absence of any other sequence of hexabothriid monogeneans in databases, further comments are useless. Our sequences of S. euzeti n. sp. might be useful only when other hexabothriid sequences are available.

\section{Taxonomic summary}

Type-host: Dalatias licha (Bonnaterre, 1788) (Dalatiidae). Type-Locality: Off Dellys ( $\left.36^{\circ} 55^{\prime} \mathrm{N} ; 3^{\circ} 53^{\prime} \mathrm{E}\right)$, Algeria.

Additional localities: Off Cap Djenet ( $\left.36^{\circ} 43^{\prime} \mathrm{N} ; 3^{\circ} 36^{\prime} \mathrm{E}\right)$, off Bou Haroun (36 40' N; $\left.4^{\circ} 40^{\prime} \mathrm{E}\right)$, off Cherchell ( $\left.36^{\circ} 37^{\prime} \mathrm{N} ; 2^{\circ} 11^{\prime} \mathrm{E}\right)$, Algeria; all these localities are within $100 \mathrm{~km}$ of Algiers.

Site of infection: gills

Type-specimens: Holotype MNHN HEL556, Paratypes MNHN HEL557.

Comparative material observed: One slide of Squalonchocotyle cerfontaini collected by Claude Maillard and deposited in the MNHN collections, MNHN 711H-Ti 52 (measurements in Table 1). Prevalence: 85/100 (85\%).

Etymology: named in honour of Professor Louis Euzet, famous parasitologist and author of major works on hexabothriids, who examined the specimens and confirmed their interest. 


\section{Remarks}

Species included in Squalonchocotyle

Species attributed to Squalonchocotyle Cerfontaine, 1899 include: S. borealis (Van Beneden, 1853), the type-species, and S. abbreviata (Olsson, 1876) Cerfontaine, 1899, S. cerfontaini Maillard, 1970, S. centrophori Maillard, 1970, S. laymani Yamaguti, 1958, S. mitsukurii Kitamura, Ogawa, Taniuchi et Hirose, 2006, S. rajae Brinkmann, 1971, S. spinacis (Goto, 1894), S. squali MacCallum, 1931, and S. tropai (Tendeiro et Valdez, 1955) (Van Beneden, 1853; Olsson, 1876; Goto, 1894; Cerfontaine, 1899; MacCallum, 1931; Tendeiro \& Valdez, 1955; Yamaguti, 1958; Maillard, 1970; Brinkmann, 1971; Kitamura et al., 2006)

Boeger \& Kritsky (1989) included only four species in the genus: S. borealis, S. cerfontaini, S. centrophori, and S. squali. They considered that $S$. somniosi (Causey, 1926) was a synonym of $S$. borealis, but did not comment on the other species they considered as "unconfirmed".

Kitamura et al. (2006) apparently followed Boeger \& Kritsky (1989) when they considered their new species $S$. mitsukurii as the fifth species of the genus. They commented that the taxonomic position of $S$. spinacis was uncertain because the type-specimens were lost.

The list of species of Squalonchocotyle in WoRMS (Bray, 2004) includes nine species, i.e. the ten listed above minus $S$. rajae.

We provide here a few remarks about $S$. tropai. The species was described as Erpocotyle tropai by Tendeiro and Valdez in 1955, from Squalus acanthias (designated as $S$. fernandinus, now considered a synonym (Froese \& Pauly, 2016)) off Luanda, Angola, and never mentioned or redescribed again in the scientific literature. However, we found that Maillard (1966) in his unpublished thesis, described new specimens from the same host, collected off Sète, Mediterranean Coast, France (Maillard, 1966); his measurements are included in Table 1. Maillard did not examine the type-specimens and wrote that he could only compare with photographs (the origin and whereabouts of these photographs is unknown; the original description by Tendeiro and Valdez includes only drawings). Euzet and Maillard (1974) claimed that the types of species described by Tendeiro and Valdez were lost. Unfortunately, the slides prepared and described by Claude Maillard were not located in the Euzet collection (13,000 slides, now in MNHN, Paris) and should probably be considered lost. Maillard's thesis (1966) should be considered unpublished for nomenclatural purposes. Euzet and Maillard (1974) used the binomial Squalonchocotyle tropai but did not formally indicate that they made a new combination for this species, but it is likely that they were the authors of the current combination, as S. tropai (Tendeiro et Valdez, 1955) Euzet \& Maillard, 1974; we did not find it in earlier published works.

\section{Generic diagnosis of our specimens}

The characteristic oötype with longitudinal rows of cells ('oötype côtelé' of Euzet and Maillard, 1974) is found only in three hexabothriid genera, including Protocotyle Euzet et Maillard, 1974,
Rajonchocotyle Cerfontaine, 1899 and Squalonchocotyle. This was considered a synapomorphy uniting these three genera (Boeger \& Kritsky, 1989). Our specimens have the characteristic oötype and all characters listed for Squalonchocotyle (Boeger \& Kritsky, 1989, and in Justine, 2011) i.e. distal cirrus unarmed, ovary branched in its proximal part, two egg filaments, vaginal ducts parallel, seminal receptacle present, and thus belong to the genus.

\section{Species diagnosis}

In the following discussion, we do not consider S. rajae; whether the species is valid and is really a member of Squalonchocotyle is an interesting question, since it is the only member of the genus described from rays (Raja smirnovi, $R$. rosispinis and Breviraja isotrachys) (Brinkmann, 1971); this is outside of the scope of this paper, but we are confident that the new species described here is distinct from S. rajae, on the basis of very different hosts (Rays vs Sharks) and widely separate localities (North Western Pacific vs Mediterranean).

We found that species of Squalonchocotyle can be separated into two groups according to body length: a group of seven relatively small species includes $S$. abbreviata, S. centrophori, S. cerfontaini, S. mitsukurii, S. spinacis, S. squali, and S. tropai (Table 1); a group of relatively large species includes $S$. borealis, $S$. laymani and S. euzeti n. sp. (Table 2). It cannot be excluded, however, that some of the small species were described from immature specimens, as it was the case for Mobulicola dubium (Euzet \& Maillard, 1974) Patella \& Bullard, 2013 (Euzet \& Maillard, 1967; Patella \& Bullard, 2013).

Squalonchocotyle euzeti is differentiated from $S$. laymani by much longer sclerites (ca 2,000 vs ca 600), different hosts (Dalatias licha vs Mustelus manazo) and widely separated localities (Mediterranean vs Japan). We measured sclerites on the figures of $S$. borealis by Cerfontaine, and found that they were of similar size to $S$. euzeti. Differential characters include body length $(7-21$ $\mathrm{mm}$ vs $25-30$ in $S$. borealis) and, more importantly, body width (777 - 1,813 vs $3,000-4,000$ in $S$. borealis) which gives to $S$. euzeti n. sp. a characteristic slender body. Since our specimens were flattened, we consider that their slender body is a genuine condition and not a consequence of insufficient flattening. Therefore, we consider that the slender body separates $S$. euzeti from $S$. borealis. In addition, the hosts are different ( $D$. licha vs Somniosus microcephalus) and the localities are separate (Mediterranean vs Northern Atlantic).

\section{Discussion}

The family Hexabothriidae has been the focus of several revisionary works, including a revision with historical account (Euzet \& Maillard, 1974) and a revision associated with a cladistic analysis (Boeger \& Kritsky, 1989). The number of genera included in the family has slowly increased from eleven (Euzet \& Maillard, 1974) and thirteen (Boeger \& Kritsky, 1989) to a total of fifteen in most 


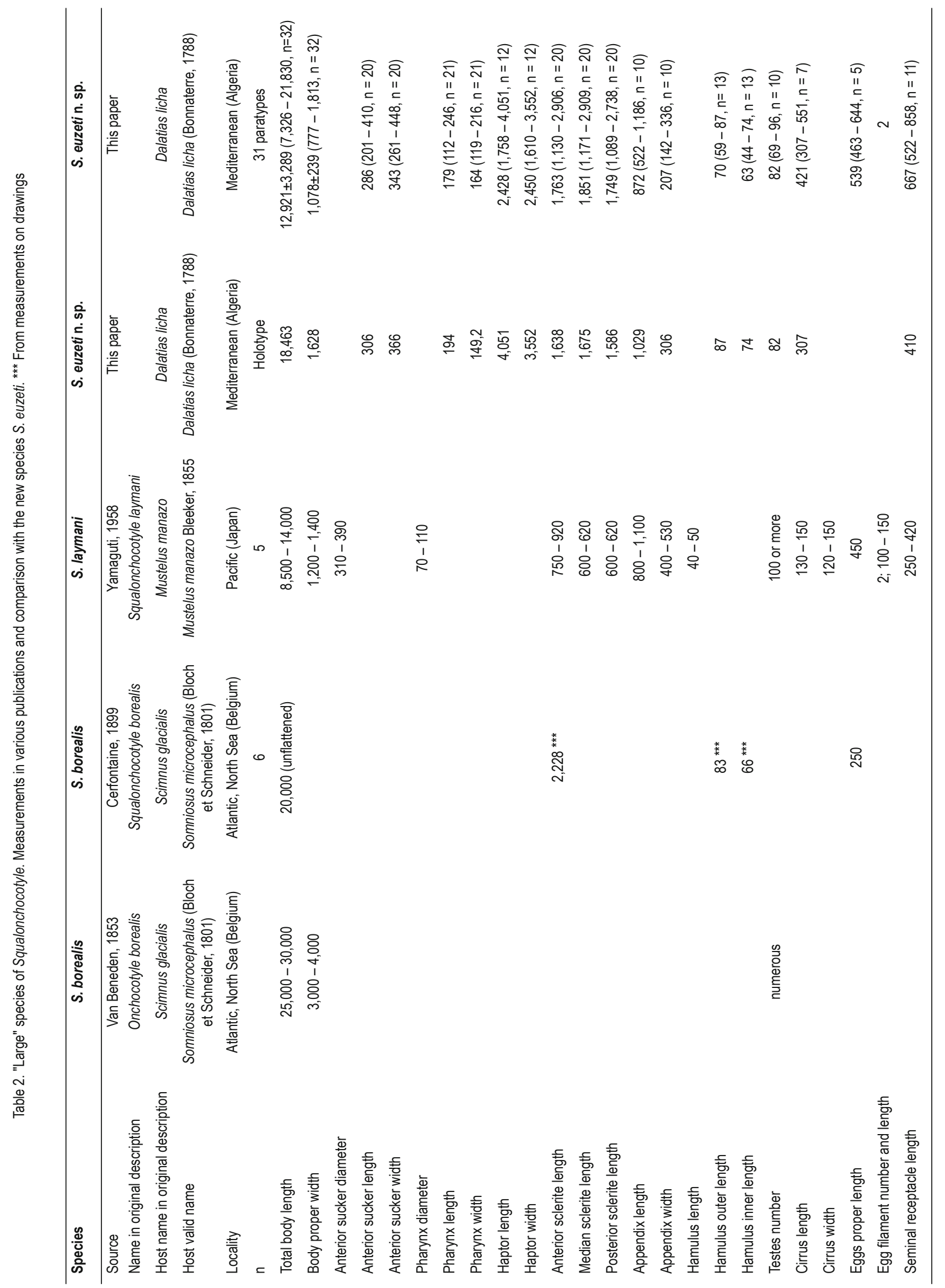




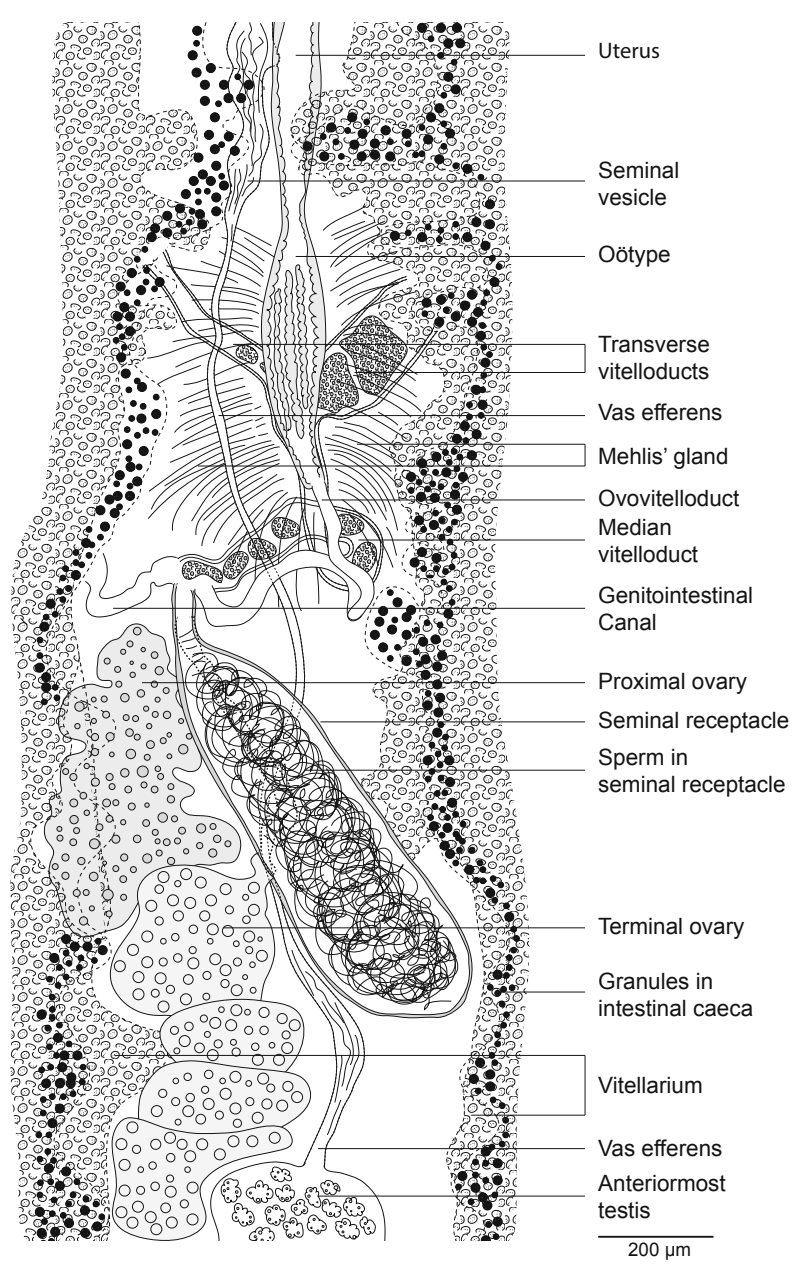

Fig. 3. Squalonchocotyle euzeti n. sp.

Anatomy of median part of reproductive system

recent works (Patella \& Bullard, 2013). However, the hexabothriid literature is plagued with confusion and discrepancies (Vaughan \& Christison, 2012) but probably no more than any large family of monogeneans. The Hexabothriidae are considered a basal group within the Polyopisthocotylea in phylogenies based on morphology (Boeger \& Kritsky, 1993) and molecules (Mollaret et al., 2000; Jovelin \& Justine, 2001; Olson \& Littlewood, 2002). Our survey of deep-sea sharks, with many negative results, emphasizes one of the major problems with hexabothriids, which is that specimens are rare. For Squalonchocotyle, our Tables show that most species have been described from a very small number of specimens. Whittington and Chisholm (2003) commented upon the low number of monogeneans in sharks, remarked that only 15 species of hexabothriids had been described from sharks, and proposed several biases which could explain these low numbers. One of the biases is the lack of sampling (Whittington \& Chisholm, 2003); after more than 700 sharks investigated, we believe, however, that even large samplings provide only a limited number of hexabothriid species.
Our study also emphasizes the very small number of molecular sequences available for members of this family - so far, our COI sequence of Squalonchocotyle euzeti $n$. sp. is the first for the family, and a research on Hexabothriidae in GenBank (date: June 9, 2016) returns only 17 sequences, from a very small total number of three species; this, however, might improve in the future.

\section{Acknowledgements}

Delphine Gey (Service de Systématique Moléculaire, UMS 2700 CNRS, MNHN, Paris) produced the new sequences presented in this paper. This work was supported by MNHN grants "ATM Barcode" and "ATM PARSUDMED" and the Mistrals ENVI-MED project BIOPARMED (Ministère des Affaires Étrangères, France).

\section{References}

Boeger, W.A., Kritsky, D.C. (1989): Phylogeny, coevolution, and revision of the Hexabothriidae Price, 1942 (Monogenea). Int. J. Parasitol., 19: 425 - 440. DOI: 10.1016/0020-7519(89)90099-4 Boeger, W.A., Kritsky, D.C. (1993): Phylogeny and a revised classification of the Monogenoidea Bychowsky, 1937 (Platyhelminthes). Syst. Parasitol., 26: 1 - 32. DOI: 10.1007/BF00009644 Bowles, J., BLAIR, D., McManus, D.P. (1995): A molecular phylogeny of the human schistosomes. Mol. Phylogenet. Evol., 4(2): 103 - 109. DOI: 10.1006/mpev.1995.1011

BraY, R.A. (2004): Squalonchocotyle Cerfontaine, 1899. Accessed through: World Register of Marine Species at http://www.marinespecies. org/aphia. php?p=taxdetails\&id=119365 on 2016-06-07. BRINKMANN, A.J. (1971): Hexabothriids (Monogeneoidea) from far eastern skates. Parazitologiya, 5: 532 - 538 (In Russian)

Cerfontaine, P. (1899): Contribution à l'étude des Octocotylidés. V. Les Onchocotylinae. [Contribution to the study of octocotylids. V. Onchocotylinae]. Arch. Biol., 16: 345 - 478 (+ Plates XVIII - XXI) (In French)

DILlon, W.A., HARGIS, W.J., JR. (1968): Monogenetic Trematodes from the Southern Pacific Ocean. Part IV. Polyopisthocotyleids from New Zealand Fishes: The families Mazocraeidae, Diclidophoridae dnd Hexabothriidae. Proc. Biol. Soc. Wash., 81: $351-366$

Euzet, L., Maillard, C. (1967): Parasites de Poissons de mer ouest-africains, récoltés par J. Cadenat. VI. Monogènes de Sélaciens. [Parasites of West-African marine sea fish, collected by J. Cadenat. VI. Monogeneans of Selacians]. Bull. Inst. Fondam. Afr. Noire Ser. A Sci. Nat., 24(4): 1435 - 1493 (In French)

Euzet, L., Maillard, C. (1974): Les Monogènes Hexabothriidae Price, 1942. Historique, systématique, phylogenèse. [The monogenean Hexabothriidae Price, 1942. History, systematic, phylogeny]. Bull. Mus. Natl. Hist. Nat. $3^{\circ}$ série, 206, Zoologie, 136: 113 - 141 (In French)

Fischer, W., BAuchot, M.-L.Schneider, M. (1987): Fiches FAO d'identification des espèces pour les besoins de la pêche. (Révision 1). Méditerranée et mer Noire. Zone de pêche 37. Volume II. 
Vertébrés. [ FAO Files for the Identification of species for fisheries purposes. (Revision 1). Mediterranean and Black Sea. Fishing area 37. Volume II. Vertebrates.]. Publication prepared by FAO, the result of an agreement between FAO and the Commission of the European Communities (Project GCP / INT / 422 / EEC) financed jointly by these two organizations. Rome, FAO, Vo1.2: 761 - 1530 (In French)

Froese, R., Pauly, D., ed. (2016): FishBase. World Wide Web electronic publication. www.fishbase.org

Gото, S. (1894): Studies on the ectoparasitic Trematodes of Japan. Edition, Tokyo

Jovelin, R., JustinE, J.-L. (2001): Phylogenetic relationships within the polyopisthocotylean monogeneans (Platyhelminthes) inferred from partial 28S rDNA sequences. Int. J. Parasitol., 31: 393 - 401 Justine, J.-L. (2011): Protocotyle euzetmaillardin. sp. (Monogenea, Hexabothriidae) from the bigeye sixgill shark Hexanchus nakamurai Teng (Elasmobranchii, Hexanchidae) off New Caledonia. Syst. Parasitol., 78: 41 - 55. DOI: 10.1007/s11230-010-9275-6

Justine, J.-L., Rahmouni, C., Gey, D., Schoelinck, C.Hoberg, E.P. (2013): The monogenean which lost its clamps. PLOS ONE 8(11): e79155. DOI: 10.1371/journal.pone.0079155

Kitamura, A., Ogawa, K., Taniuchi, T., Hirose, H. (2006): Two new species of hexabothriid monogeneans from the ginzame Chimaera phantasma and shortspine spurdog Squalus mitsukurii. Syst. Parasitol., 65(2): 151 - 159. DOI: 10.1007/s11230-006-9046-6

LitTlewood, D.T.J., Rohde, K., Clough, K.A. (1997): Parasite speciation within or between host species? - Phylogenetic evidence from site-specific polystome monogeneans. Int. J. Parasitol., 27: 1289 - 1297. DOI: 10.1016/S0020-7519(97)00086-6

MacCallum, G.A. (1931): Four new species of Trematode worms of the subfamily Onchocotylinae. Proc. U. S. Nat. Mus., 79: $1-8$. DOI: 10.5479/si.00963801.79-2892.1

MaILlaRd, C. (1966): Études sur les Hexabothriidae (Monogenea) parasites des Sélaciens de la région de Sète. [Studies on Hexabithriidae (Monogenea) parasites in Selacians in the region of Sète]. PhD Thesis, Thesis, Université de Montpellier, France (In French)

MaILlARD, C. (1970): Trois nouvelles espèces d'Hexabothriidae (Monogenea) parasites de Sélaciens du Golfe du Lion. [Three new species of Hexabothriidae (Monogenea) parasites of Selacians in the Gulf of Lion]. Ann. Parasitol. Hum. Comp., 45(5): 563 - 576 (In French)

Malllard, C., Oliver, G. (1966): Monogenea, Hexabothriidae. Vie Milieu A: Biol. Ma., 17(3A): 1201 - 1216
Martorelli, S.R., Marcotegui, P.S.Suriano, D.M. (2008): Squalonchocotyle squali MacCallum (Monogenoidea, Hexabothriidae) on Squalus acanthias Linneus (Elasmobranchii, Squalidae) from the Atlantic coast of Argentina. Pan-Am. J. Aquat. Sci., 3(1): 14 - 17 Mollaret, I., Jamieson, B.G.M., Justine, J.-L. (2000): Phylogeny of the Monopisthocotylea and Polyopisthocotylea (Platyhelminthes) inferred from 28S rDNA sequences. Int. J. Parasitol., 30: 171 - 185 OLSON, P.D., LITTLEWOOD, D.T.J. (2002): Phylogenetics of the Monogenea - evidence from a medley of molecules. Int. J. Parasitol.I, 32: $233-244$

OLsson, P. (1876): Bidrag till skandinaviens helminthfauna. I. [Study of scandinavian helminthofauna. I.] K. Sven. vetensk. akad. handl., 14(1): 1 - 41 (In Swedish)

Patella, R., Bullard, S.A. (2013): Hexabothriids of devil rays (Mobulidae): new genus and species from gill of Mobula hypostoma in the Northern Gulf of Mexico and redescription of a congener from Mobula rochebrunei in the eastern Atlantic Ocean. J. Parasitol., 99(5): 856 - 867. DOI: 10.1645/12-153.1

PrICE, E.W. (1942): North American monogenetic trematodes. V. The family Hexabothriidae n. n. (Polystomatoidea). Proc. Helminthol. Soc. Wash., 9(2): $39-56$

TendeIRo, J., Valdez, V. (1955): Helmintologica ictiológica. Helmintes de alguns peixes da Costa Oeste-Africana. [Ichthyological helminthology. Helminths of some fish of the West-African coast]. Bol. Cult. Guiné. Port., 37: 129 - 166 (In French)

VAn Beneden, P.-J. (1853): Espèce nouvelle du genre Onchocotyle, vivant sur les branchies du Scimnus glacialis. [New species of genus Onchocotyle, living on the gills of Scimnus glacialis]. Bull. Acad. R. Belg., 20(9): 59 - 68 (In French)

VAUGHAN, D., ChRISTISON, K. (2012): Towards addressing the current state of confusion within the Hexabothriidae Price, 1942 (1908): Callorhynchocotyle Suriano \& Incorvaia, 1982 (Monogenea: Hexabothriidae) re-visited, with the preliminary evaluation of novel parameters for measuring haptoral armature of hexabothriids. Zootaxa, 3229: 1 - 34. DOI: 10.15468/6tmpcn

WhitTIngton, I.D., Chisholm, L.A. (2003): Diversity of Monogenea from Chondrichthyes: do monogeneans fear sharks? In: Taxonomie, écologie et évolution des Métazoaires parasites. [Taxonomy, Ecology and Evolution of Metazoan Parasites]. Livre-hommage à Louis Euzet, Vol II. Combes, C. \& Jourdane, J. (Eds). Perpignan: Presses Universitaire de Perpignan, pp. 339 - 363 (In French) Yamaguti, S. (1958): Studies on the helminth fauna of Japan. Part 53. Trematodes of fishes, XII. Publ. Seto Mar. Biol. Lab., 7: 53 - 88 